March 2006

\title{
Foreword: Anti-angiogenic therapy: Maximizing therapeutic gain
}

Adam P. Dicker

Thomas Jefferson University

Follow this and additional works at: https://jdc.jefferson.edu/radoncfp

Part of the Radiology Commons

Let us know how access to this document benefits you

\section{Recommended Citation}

Dicker, Adam P., "Foreword: Anti-angiogenic therapy: Maximizing therapeutic gain" (2006).

Department of Radiation Oncology Faculty Papers. Paper 3.

https://jdc.jefferson.edu/radoncfp/3

This Article is brought to you for free and open access by the Jefferson Digital Commons. The Jefferson Digital Commons is a service of Thomas Jefferson University's Center for Teaching and Learning (CTL). The Commons is a showcase for Jefferson books and journals, peer-reviewed scholarly publications, unique historical collections from the University archives, and teaching tools. The Jefferson Digital Commons allows researchers and interested readers anywhere in the world to learn about and keep up to date with Jefferson scholarship. This article has been accepted for inclusion in Department of Radiation Oncology Faculty Papers by an authorized administrator of the Jefferson Digital Commons. For more information, please contact: JeffersonDigitalCommons@jefferson.edu. 


\title{
FOREWORD: ANTI-ANGIOGENIC THERAPY: MAXIMIZING THERAPEUTIC GAIN
}

\author{
Adam P. Dicker, MD, PHD \\ Department of Radiation Oncology, Kimmel Cancer Center, Jefferson Medical College \\ of Thomas Jefferson University, Philadelphia, PA
}

On June 25, 2004, the Radiation Therapy Oncology Group (RTOG, www.rtog.org) held a symposium, "Anti-Angiogenic Therapy: Maximizing Therapeutic Gain," in Washington, D.C., in conjunction with the RTOG's semi-annual meeting.

The symposium brought together a diverse group of clinicians and basic scientists, leading experts in the field, to foster the development of innovative research in multicenter cooperative group projects. The topics covered were the following: role of angiogenesis in normal tissue biology and cancer cell biology, mechanism of action in tumor-growth inhibition of selective anti-angiogenic inhibitors, effects of anti-angiogenic inhibitors on preclinical tumor models alone and in combination with cytotoxic chemotherapy and radiation therapy, issues regarding clinical trial design using novel agents, and the results of clinical trials using inhibitors of angiogenesis alone or in combination with radiation or chemotherapy.

I would like to acknowledge the advice and support of Dr. Walter Curran, Jr., chairman of the RTOG, and Tom Wudarski and Sharon Hartson Stine, who provided logistical support and help with visual materials. I would also like to acknowledge the helpful feedback and counsel of members of the Translational Research Program, including Drs. Luka Milas and Paul Okunieff.

Reprint requests to: Adam P. Dicker, M.D., Ph.D., Department of Radiation Oncology, Kimmel Cancer Center, Jefferson Medical College of Thomas Jefferson University, 111 South 11th Street, Philadelphia, PA 19107-5097. Tel: (215) 955-6527; Fax: (215) 9550412; E-mail: adam.dicker@mail.tju.edu 